\title{
ПРИНЦИП СОЦІАЛЬНОЇ СПРАВЕДЛИВОСТІ В КОНСТИТУЦІЙНОМУ ПРАВІ
}

Шелевер Н. В.

У статті досліджено принцип соціальної справедливості в конституційному праві. Ця тема не $\epsilon$ новою для України, оскільки багато науковців приділяють їй велику увагу. Проте нині з огляду на ситуацію, яка склалася в нашій державі (пандемія коронавірусу COVID-19, війна на сході України, економічна криза, масова міграція, нова судова реформа), доцільним $\epsilon$ дослідження реалізації принципу справедливості на практиці. Автор аналізує проблеми, які виникають, та вказує на шляхи їх вирішення.

Принцип соціальної справедливості відображається в розділі II Конституції України. Автор акцентує, що в Конституції Японії та Іспанії закріплено не лише соціальні гарантії для громадян, але й обов'язок працювати. Показником несправедливості в Україні $\epsilon$ великий розрив між мінімальною і максимальною заробітною платою, пенсією. Великі заробітні плати та пенсії $\epsilon$ необгрунтованими та несправедливими в такій бідній державі, як Україна. У цій статті звертається також увага на несправедливо великі заробітні плати суддів. Автор робить висновок, що в найбіднішій державі Європи недоцільно надавати таку заробітну плату суддям, оскільки вона не $\epsilon$ стримуючим фактором в отриманні хабарів. Проблемою в Україні $\epsilon$ саме відсутність реальної відповідальності.

Автор акцентує на тому, що в Конституціі України не закріплений термін «соціальна справедливість», що є суттєвою прогалиною. Прожитковий мінімум у нашій державі свідчить про те, що українці знаходяться на межі виживання. Якщо у Франціі у прожитковий мінімум включені вино і відвідування ресторану, в Німеччині - пиво, у Великобританії витрати на гру в гольф, то в Україні зовсім інакша ситуація.

Автор звертає увагу на те, що в нашій державі принцип справедливості не реалізовується повною мірою. Карантин, війна на сході України, безробіття, корупція, імітація проведення реформ, економічна криза призводять до масової міграції населення України до держав-членів Європейського Союзу в пошуках кращого життя і справедливості. Такий стан справ у недалекому майбутньому може перетворити Україну на «державу пенсіонерів та корупиіонерів». Нестабільна економічна ситуація, корупція, порушення принципу верховенства права, відсутність справедливості призводять і до того, що іноземні інвестори не вкладають свої кошти в економіку України, бо не мають жодних гарантій для успішного ведення бізнесу. Тому для виходу з кризи необхідним кроком $\epsilon$ проведення дієвих реформ у нашій державі.

Ключові слова: сочіальна справедливість, держава, суддя, споживчий кошик, пандемія коронавірусу COVID-19, війна на сході України, Європейський Союз.

Shelever N. V. Principle of social justice in constitutional law

The article examines the principle of social justice in constitutional law. This topic is not new in Ukraine, as many scientists pay much attention to it. However, at present, given the current situation in our country, namely the COVID-19 coronavirus pandemic, the war in eastern Ukraine, the economic crisis, mass migration, new judicial reform, it is advisable to study the implementation of the principle of justice in practice. The author points out the problems that arise and points out ways to solve them.

The principle of social justice is reflected in Section II of the Constitution of Ukraine. The author emphasizes that the Constitutions of Japan and Spain enshrine not only social guarantees for citizens, but also the obligation to work. An indicator of injustice in Ukraine is the large gap between the minimum and maximum wages, pensions. High wages and pensions are unjustified and unfair in a country as poor as Ukraine. This article also draws attention to the unfairly high salaries of judges. The author concludes that in the poorest country in Europe it is not advisable to provide such a salary to judges, as it is not a deterrent to not receiving bribes. The problem in Ukraine is the lack of real responsibility of the official.

The author emphasizes that the Constitution of Ukraine does not enshrine the term "social justice", which is a significant gap. The subsistence level in our country indicates that Ukrainians are on the verge of survival. If in France in subsistence going to a restaurant and wine are incluced, in Germany beer, in Great Britain - expenses for a game of golf, in Ukraine the situation is absolutely different.

The author draws attention to the fact that in our country the principle of justice is not fully implemented. Quarantine, war in eastern Ukraine, unemployment, corruption, imitation of reforms, economic crisis lead to 
mass migration of the population of Ukraine to the member states of the European Union in search of a better life and justice. This state of affairs may turn Ukraine into $a$ "state of pensioners and corrupt officials" in the near future. Unstable economic situation, corruption, violation of the rule of law, lack of justice also lead to the fact that foreign investors do not invest in the economy of Ukraine, because they have no guarantees for successful business. Therefore, effective reforms in Ukraine are a necessary step to overcome the crisis.

Key words: social justice, state, judge, the consumer basket, the COVID-19 coronavirus pandemic, the war in eastern Ukraine, European Union.

Постановка проблеми та іï актуальність. В Основному Законі України встановлено, що Україна - суверенна і незалежна, демократична, соціальна, правова держава [1]. Одним з основних елементів категорії «соціальна держава» $\epsilon$ принцип соціальної справедливості. Проте в Конституції України відсутній термін «соціальна справедливість», що $€$ прогалиною у чинному законодавстві.

О. Сидоренко зазначає: «Соціальна справедливість має свій конкретний сенс для кожного покоління, інтерес до проблеми справедливості особливо зростає в епоху кризи і змін, зміни цінностей і традицій. Сучасна епоха - епоха глобальних змін. Серед основоположних універсалій соціальна справедливість займає особливе місце. Вагомість цієї категорії полягає у значенні, яку вона відіграє у всіх сферах життя суспільства. В той самий час широка сфера застосування принципів соціальної справедливості зумовила складність і неоднозначність в її розумінні. Теоретичне розроблення проблем соціальної справедливості на сучасному етапі розвитку має сприяти суттєвому внеску у формування духовних основ майбутнього суспільства, досягненню згоди, гармонізації соціальних відносин» [2].

Аналіз останніх досліджень і публікацій. Тема цієї статті не $\epsilon$ новою. Ї̈̈ дослідженням займалися такі вчені, як О. Сидоренко, П. Корнєва, В. Опришко, І. Чечельницький, В. Чіркін, Я. Фогель тощо. Проте нині Україна знаходиться у таких складних умовах, що виникла необхідність дослідження реалізації принципу справедливості під час пандемії коронавірусу COVID-19, проведення нової судової реформи, війни на сході України та економічної кризи.

Метою статті $\epsilon$ дослідження правового змісту принципу соціальної справедливості, виділення проблем, які виникають у процесі реалізації цього принципу на практиці, та аналіз шляхів їх вирішення.
Виклад основного матеріалу. В.Є. Чіркін зазначає: «У перших конституціях держав світу не було соціальних положень, крім проголошення влади народу і недоторканності приватної власності, вони обмежувалися регулюванням системи вищих органів держави, деяких особистих і політичних прав людини і громадянина (положень про соціально-економічні права не було). Соціальні положення вперше з'явилися в Конституції Мексики 1917 р., що прийнята під час народної революції, потім (із класових позицій) - у Конституції РСФСР 1918 р., пізніше - у Веймарській Конституції Німеччини 1919 р., яка теж була підсумком революційних подій та інколи помилково вважається в західній літературі «першою соціальною конституцією». Тепер соціально-економічні положення $\epsilon$ в конституціях різних держав (наприклад, Гани 1992 р., Бразилії 1988 р., в Основному низамі про управління Саудівської Аравії 1992 р.).

Положення, яке наближене до поняття соціальної справедливості, вперше, мабуть, було включене в 1937 р. в конституцію Ірландії, яка боролася проти англійського панування. У ній йшлося про те, що має існувати такий «соціальний порядок», за якого “справедливість, поряд із благодійністю, має надихати всі інститути державного життя» (ст. 45).

Поява в конституціях терміна «соціальна справедливість» - результат впливу соціалістичних вчень (не тільки марксизму) і норм права тоталітарного соціалізму. Практика такого соціалізму мала збочений характер, але положення соціалістичних конституцій (якась інформація про них за кордоном все-таки була) справляли великий вплив на трудове населення інших держав» [3, с. 6].

Принцип соціальної справедливості відображається в розділі ІІ Конституції України: ст. 46 право на соціальний захист, що включає право на забезпечення їх у разі повної, часткової або тимчасової втрати працездатності, втрати годувальника, безробіття з незалежних від них обставин, а також у старості та в інших випадках, передбачених законом; ст. 47 - право на житло. Держава створює умови, за яких кожен громадянин матиме змогу побудувати житло, придбати його у власність або взяти в оренду; ст. 48 - право на достатній життєвий рівень для себе і своєї сім'ї, що включає достатнє харчування, одяг, житло; ст. 49 - право на охорону здоров'я, медичну допомогу та медичне страхування; ст. 50 - право на безпечне для життя і здоров'я довкілля та на відшкодування завданої порушенням цього права шкоди тощо [1]. 
Варто зазначити, що принцип соціальної справедливості полягає не тільки в наданні соціальних гарантій громадянам, але і в покладенні на них відповідних обов'язків. У Конституції Японії, Іспанії закріплюється обов'язок громадян працювати. Кожному наданому праву має відповідати обов'язок. І сприяти в досягненні соціальної справедливості мають і держава, і громадяни.

І.В. Чечельницький слушно зазначає: «<...> справедливість $\epsilon$ універсальним мірилом поведінки і світогляду людини, $є$ моральною основою і засобом забезпечення цінності права і правотворчості. Справедливість $\epsilon$ «альфою і омегою» вирішення найбільш актуальних питань сучасної юридичної науки: починаючи, наприклад, від галузевих проблем індивідуалізації покарання, відшкодування матеріальної і моральної шкоди, сплати податків чи аліментів, забезпечення екологічних інтересів громадян i закінчуючи комплексними загальноправовими проблемами правотворчості, правозастосування, правосвідомості і праворозуміння» $[4$, c. 100$]$.

В.Є. Чіркін досліджував індикатори принципу соціальної справедливості в конституційному праві і зазначає: «Ще один індикатор (його в конституціях нема) - порівняння життєвого рівня 10\% найбагатших і $10 \%$ бідних. В Європі такий розрив становить 7-8 разів, в США - 15, в Росії за офіційними даними - більше 15, а за підрахунками незалежних економістів цей показник значно вищий. Існує певний розрив у фактичних доходах чиновників та інших громадян. У квітні 2016 р. опубліковані чергові декларації про доходи посадових осіб, в тому числі їхніх жінок. Зрозуміло, що деякі заходи держави дають результати. Але знову видно, що певна кількість чиновників (у тому числі і міністри), їхні жінки «заробляють» майже по мільйону рублів на день (буває і більше), дорослі діти менше, а інколи в малих дітей $\epsilon$ доходи. Як треба працювати зайнятим 24 години на добу державним службовцям, які заробляють такі гроші? Про заборону трасту (довірчої власності, коли чиновник юридично підприємництвом не займається, а отримує тільки дохід із цього) багато говорили в парламенті ще в 2013 р., щось зроблено (наприклад, заборона мати іноземні акції), але юридично траст не відмінили. Щоправда, він існує і в інших державах (наприклад, у США), але там ставлення до державної служби трохи інакше - в менталітеті вона менше розглядається як джерело доходів. Існують й інші проблеми здійснення складових частин конституційних принципів, у тому числі принципу соціальної справедливості - важливо вивчати їх фактичну реалізацію в цифрових даних, а не тільки термінологію. Це непросто. Але без цього в наш час не можна вивчати конституційне право, державознавство і навіть теорію права. Потрібно розробляти нові підходи» [5].

Щодо України, то тут також спостерігається великий розрив між багатим населенням і бідним, що $\epsilon$ порушенням принципу соціальної справедливості. Якщо в державі живуть всі приблизно однаково, то цей принцип не порушується. Так було в Радянському Союзі. Нині ми спостерігаємо в незалежній Україні зовсім інакшу ситуацію, коли різниця в заробітній платі чиновника і простого працівника $\epsilon$ величезною, а пенсії $\epsilon$ необґрунтованими i несправедливими. Декларації більшості чиновників не відповідають дійсності, а законопроєкт, який передбачав передачу майна дітям і незазначення цього чиновником у своїй декларації, міг дати йому змогу приховати своє майно. Чиновник у такому разі міг би уникнути декларування майна неповнолітніх дітей, які не проживають із декларантом. 21.07.2020 р. проєкт не прийнято.

У Конституції України не закріплений термін «соціальна справедливість», що $є$ суттєвою прогалиною. В.Є. Чіркін зауважує: «В тих конституціях, де термін «соціальна справедливість» $\epsilon$, він міститься, як правило, в преамбулах конституцій чи розділах про керівні принципи політики держави. Таке формулювання має загальний, інколи лозунговий характер, його зміст не розкривається, а правове застосування заздалегідь конституціями обмежено. В конституціях йдеться про те, що та ії частина, в якій знаходиться цей принцип і інші соціальні положення, має «основоположне значення для управління державою», але такі положення «не мають здійснюватися в порядку судового примусу» (ст. 37 Конституції Індії 1949 р.). Конституція Албанії 1998 р. повторює, що «добиватися соціальних цілей безпосередньо через суд не можна» (ч. 2 ст. 59). У Конституції Швейцарії 1999 р. сказано: «Із соціальних цілей не можуть виводитися ніякі безпосередні претензії на державні послуги» (п. 4 ст. 41). Це, а також відсутність визначень, вказівок на суть і елементи принципу соціальної справедливості знижують його регулятивне значення.

Принцип соціальної справедливості, який визначає умови життя соціуму, належить до основ суспільного і державного ладу, статусу людини. Ось чому при соціально різних правових системах він має неоднакові елементи і різні індикатори. 
Загалом можна сказати, що нині у світі діють три глобальні правові системи - мусульманська (приблизно 20 держав i, за підрахунками мусульманських джерел, 1,7 млрд людей, що живуть компактно і розрізнено в найрізноманітніших державах, наприклад, у Франції 5,8 млн мусульман), тоталітарно-соціалістична (п'ять держав із загальним населенням більше 1,5 млрд людей) і ліберально-напівсоціальна капіталістична (більшість держав із населенням більше 4 млрд людей)» [3, с. 7].

Важливим індикатором соціальної справедливості $€$ прожитковий мінімум. П. Корнєва зазначає: «Прожитковий мінімум застосовується для встановлення розмірів мінімальної заробітної плати і мінімальної пенсії за віком, визначення розміру соціальної допомоги, допомоги сім'ям із дітьми, виплати по безробіттю, а також стипендій та інших соціальних виплат з огляду на вимоги Конституції України і законів України.

На підставі прожиткового мінімуму мають визначатися і державні соціальні стандарти. Метою встановлення державних соціальних стандартів і нормативів $\epsilon$ визначення механізму реалізації соціальних прав і державних соціальних гарантій громадян, визначених Конституцією України, встановлення пріоритетів державної соціальної політики із забезпечення потреб людини в матеріальних благах і послугах і фінансових ресурсів для їх реалізації, визначення і обґрунтування розмірів потреб у коштах Державного бюджету України і місцевих бюджетів, соціальних фондів на соціальний захист і зміст соціальної сфери.

На жаль, поки що реального перегляду базового державного соціального стандарту з урахуванням індексу споживчих цін на практиці не було. Фактично в Україні вибраний шлях забезпечення фізіологічної споживчої корзини, яка складається із переліку товарів, необхідних для фізіологічного виживання людини. Поряд із цим у більшості країн світу на законодавчому рівні гарантується соціальний споживчий кошик, який складається із досить широкого переліку товарів і послуг, що дає змогу людині нормально існувати» [6, с. 168].

В.Є. Чіркін, досліджуючи індикатори принципу соціальної справедливості, зазначає: «Індикатор прожиткового мінімуму людини (його частина - споживчий кошик) названий інколи в загальній формі в конституціях (в Росії - ні), конкретно в цифрах - в законах. Частиною прожиткового мінімуму $є$ споживчий кошик (зазвичай на місяць, у Великобританії - на тиждень). Інші товари визначаються на триваліший період (наприклад, строки для заміни пальто чи суконь роки). У Росії прожитковий мінімум загалом включає 156 видів товарів і послуг, у Німеччині - 475, Великобританії - 700. Інколи прожитковий мінімум відтворює менталітет народу. У Франції сюди включено вино і відвідування ресторану, у Німеччині - пиво, у Великобританії - витрати на гру в гольф (в Росії, зрозуміло, горілки нема). Прожитковий мінімум у розвинутих країнах (США) становить 40-50\% середньої заробітної плати. Нема такого доходу - держава (в Росії також) доплачує субсидію до цього показника» [5].

На думку О. Сидоренко, «правові установки, що не відповідають справедливості, втрачають моральну цінність і гуманістичний зміст. Право має підтримувати вимоги принципу соціальної справедливості, в протилежному випадку, існування суспільства буде під питанням, адже дотримання встановлених державою правових норм істотно залежить від переконань людей у справедливості панівних у ній принципів законності.

Своєю чергою соціальна справедливість, впливаючи на право, сама потребує опори на відповідні правові норми. У праві вимоги принципу соціальної справедливості набувають чітко сформульований, фіксований характер. Цінність права і полягає в тому, що воно виражає ідею справедливості, виступає засобом їі закріплення і захисту. Розробка проблем соціальної справедливості має відіграти значну роль в юридичній науці, дати основу для глибшого розуміння цінності людини, iї життя і гідності» [2].

Нині Україна знаходиться в дуже складних умовах, адже пандемія коронавірусу COVID-19, війна на сході, безробіття, корупція, імітація проведення реформ, економічна криза призводять до масової міграції населення до держав-членів Європейського Союзу в пошуку кращого життя.

Україна визнана найбіднішою країною Європи за часткою ВВП на душу населення, а за рівнем злочинності посідає перше місце. За даними звіту МВФ, Молдова має показник \$2694 ВВП на людину, тоді як в Україні \$2656. Найкращі показники - у Люксембурзі (понад \$100 тисяч). Такий невтішний стан справ призводить до того, що в недалекому майбутньому наша держава може перетворитися на «державу пенсіонерів та корупціонерів». Працездатне населення виїжджає в ті країни, де панує закон, є справедливість та гідні умови життя.

За такої ситуації іноземні інвестори не вкладають кошти в економіку України. Для цього треба ліквідувати корупцію, вивести економіку з тіні, 
провести податкову реформу, забезпечити ефективний судовий захист іноземних інвесторів.

Ми цілком погоджуємося з думкою В. Опришко: «Незважаючи на економічну ситуацію, в державі $\epsilon$ різкі відмінності в оплаті праці від найнижчих до найвищих, можна сказати, «захмарних». Якщо мінімальна заробітна плата в Україні в 2019 році становить 4 тис. 173 грн, то максимальна - 300 тис. грн і більше. Такий суттєвий розрив абсолютно не відповідає моральним, соціальним, правовим та іншим критеріям соціальної і правової держави, до яких держава, відповідно до положень ст. 1 Конституції України, має прагнути.

При цьому розмір мінімальної зарплати, з огляду на високі тарифи, вартість житла, ціни на продовольчі та промислові товари, лікування, інші потреби та послуги, не дає змоги реалізувати положення ст. 48 Конституції України про право кожного на гідний рівень життя для себе і своєї сім'ї, що включає достатнє харчування, одяг, житло. Незважаючи на те, що ст. 49 Конституції зобов'язує державу створити умови для ефективного і доступного для всіх громадян медичного обслуговування, здійснюваного в державних і комунальних закладах охорони здоров'я, що має надаватися безплатно, на практиці не виконується» [7].

Нині в Україні спостерігається парадоксальна ситуація, коли багаті стають багатшими, а бідні біднішають. Споживчий кошик українця не задовольняє потреби сучасної людини. Надзвичайно високими та несправедливими в найбіднішій державі Європи $є$ заробітні плати суддів. Як не дивно, більшість представників судової гілки влади вважають свої заробітні плати справедливими. Як, з огляду на таку бідність у державі, можна платити суддям такі захмарні заробітні плати?

На нашу думку, високі зарплати суддів, державних чиновників не $\epsilon$ стримуючим фактором в отриманні хабарів. Усе залежить від моральних якостей представника Феміди, його правової свідомості та правової культури. Проблемою в Україні $\epsilon$ відсутність реальної відповідальності, коли де-юре усе гарантується, а де-факто нічого не виконується. Адже багато справ стосовно корупціонерів «закриваються» в суді і робота правоохоронних органів зводиться нанівець.

В. Опришко зауважує: «Високі зарплати часто - це свого роду хабар від можновладців тим, кому вони призначають високу зарплату. Тим самим держава ніби не довіряє працівнику, немов завідомо підозрюючи його в тім, що він уже схильний до отримання хабаря і здійснення інших корупційних дій. А це певна «аморальність» позиції держави, не кажучи уже про соціальну справедливість і її правове забезпечення.

Обійняти високу посаду в державі - перш за все питання честі i гідності людини, яка $\epsilon$ істинним громадянином і патріотом своєї країни і держави, володіє високими професійними і моральними якостями, високим рівнем правової культури. Така людина має, безперечно, отримувати гідну заробітну плату згідно з обійманою посадою, складністю професійної діяльності і відповідальності. Водночас високі зарплати окремих діячів на фоні подальшого зубожіння суспільства можуть стати причиною загострення протиріч і виникненню соціальних конфліктів. В тих умовах, в яких знаходиться наша держава і суспільство, це недопустимо» [7].

Висновки. Україна $\epsilon$ соціальною державою. Проте аналіз ситуації в країні свідчить про те, що принцип соціальної справедливості реалізовується неповною мірою. Корупція, економічна криза, пандемія коронавірусу COVID-19, війна на сході України призводять до того, що іноземні інвестори не хочуть вкладати кошти, оскільки не довіряють судовій системі, бо відсутнє верховенство права, законодавство в Україні мінливе, а корупція процвітає. Відсутність дієвих реформ у нашій державі призводить до правового нігілізму, масової міграції українців у більш розвинені держави-члени Європейського Союзу в пошуках справедливості та кращого життя. Проблемою $є$ і несправедливі заробітні плати, пенсії. $\epsilon$ великий розрив у доходах чиновників і простих громадян. Прожитковий мінімум, споживчий кошик українця свідчить про те, що Україна $є$ найбіднішою державою Європи, в тому числі й за рівнем ВВП на душу населення.

Вважаємо, що для виходу з такої кризи потрібні дієві реформи. Це проведення нової судової реформи, подолання корупції, створення сприятливих умов для іноземних інвесторів. Як справедливо зазначає В. Опришко, вирішенню проблем соціальної держави «має сприяти проведення правової реформи на основі Конституції України згідно з потребами суспільства і держави. Недосконалість нашого законодавства у всіх сферах життя людей, діяльності державних органів зумовлює необхідність глибокого вивчення і аналізу його стану, якості правового регулювання суспільних відносин, вирішення питань соціально-економічного, культурного розвитку, врахування потреб міжнародного співробітництва. Необхідна наукова Концепція розвитку законо- 
давства України на 2019-2024 роки і на їі основі розробка відповідної державної програми. До цієї роботи мають бути залучені відповідні органи державної влади і самоврядування, науково-дослідні установи, відомі в цій сфері діяльності учені і практики» [7].

\section{Література}

1. Конституція України. База даних «Законодавство України». URL: https://zakon.rada.gov.ua/laws/ show/254\%D0\%BA/96-\%D0\%B2\%D1\%80\#Text (дата звернення: 25.10.2020).

2. Сидоренко О. Социальная справедливость как основополагающий принцип устойчивого развития. URL: http://www.kbuapa.kharkov.ua/ e-book/putp/2013-2/doc/4/02.pdf (дата звернення: 27.10.2020).

3. Чиркин В.Е. Социальная справедливость в конституционном праве. Журнал российского права. № 7-2016. С. 5-12.

4. Чечельницкий И.В. Принцип справедливости в российском праве. Социально-экономические явления и процессы. 2014. Т. 9. № 7. С. 100-104.
5. Чиркин B.E. Индикаторы принципа социальной справедливости в конституционном праве в сравнительном измерении (тезисы доклада на международной конференции 19 апреля 2016 г.). URL: https://cyberleninka.ru/article/n/indikatoryprintsipa-sotsialnoy-spravedlivosti-v-konstitutsionnomprave-v-sravnitelnom-izmerenii-tezisy-doklada-namezhdunarodnoy (дата звернення: 03.11.2020).

6. Корнева П. Принцип справедливости и проблемы реализации международного социального стандарта достойного уровня жизни. Jurnalul Juridic National: Teorie si Practica. 2015. № 6 (Decembrie). C. 166-170.

7. Опришко В. Реалии социальной «справедливости» в контексте морали. URL: http://www. golos.com.ua/rus/article/320293 (дата звернення: 05.11.2020).

Шелевер Н. В., кандидатка юридичних наук, доцентка, доцентка кафедри адміністративного, фінансового та інформаційного права Ужгородського національного університету 